\title{
Physical composition of carcass, commercial cuts and meat characteristics of young bulls fed millet-based diets containing increased crude glycerin levels
}

\section{Composição física, cortes comerciais da carcaça, e características da carne de tourinhos alimentados com níveis de glicerina bruta em dietas a base de grão de milheto}

\author{
Werney da Silva Moreira ${ }^{1}$; Fabrícia Rocha Chaves Miotto ${ }^{2 *}$; João Restle ${ }^{3}$; \\ Regis Luis Missio4; José Neuman Miranda Neiva²; Denise Adelaide Gomes Elejalde ${ }^{5}$; \\ Ricciere Rodrigues Pereira Parente ${ }^{6}$; Wescley Faccini Augusto ${ }^{1}$
}

\begin{abstract}
Assessment of carcass and meat characteristics of Nellore young bulls finished in feedlot with crude glycerin levels $\left(0,60,120\right.$, and $240 \mathrm{~g} \mathrm{~kg}^{-1}$ dry matter) in millet-based diets. Twenty-eight young bulls with mean age of 18 months and average weight of $357 \pm 23.56 \mathrm{~kg}$ were used. The animals were distributed in a completely randomized design with four treatments and seven replicates. It was observed that the physical composition and edible portion of the carcass were not affected by crude glycerin levels in the diets. However, the increased dietary crude glycerin level raised the weights of the forequarters ( $\mathrm{kg}$ and $\%$ of cold carcass weight), but not that of the pistol cut and short ribs. Among the commercial cuts prepared to marketing of the pistol cut, only the weight of the rump cap ( $\%$ cold carcass weight) was changed, decreasing linearly with increasing dietary crude glycerin levels. Additionally, meat characteristics remained unaltered by the increased levels of crude glycerin. It was concluded that inclusion of up to $240 \mathrm{~g} \mathrm{~kg}^{-1}$ of crude glycerin in millet grain-based diets for Nellore young bulls finished in feedlot does not alter the main carcass and meat characteristics or affect their economic value.
\end{abstract}

Key words: Byproduct. Color. Glycerol. Marbling. Rump cap. Shear force.

\section{Resumo}

O objetivo do presente estudo foi avaliar as características de carcaça e carne de tourinhos Nelore terminados em confinamento com níveis de glicerina bruta $\left(0,60,120\right.$ e $240 \mathrm{~g} \mathrm{~kg}^{-1}$ da matéria seca) em dietas a base de grão de milheto. Vinte e oito tourinhos com idade média de 18 meses e peso corporal médio de $357 \pm 23,56 \mathrm{~kg}$ foram utilizados. O delineamento experimental utilizado foi o inteiramente casualizado com quatro tratamentos e sete repetições. A composição física e a porção comestível da

\footnotetext{
${ }^{1}$ Discentes do Curso de Mestrado do Programa de Pós-graduação em Ciência Animal Tropical, Universidade Federal do Tocantins, UFT, Araguaína, TO, Brasil. E-mail: werney182@hotmail.com; wescleyfaccini@hotmail.com

2 Profs., UFT, Araguaína, TO, Brasil. E-mail: fabriciarchaves@hotmail.com; araguaia2007@gmail.com

3 Bolsista PVNS CAPES, UFT, Araguaína, TO, Brasil. E-mail: jorestle@terra.com.br

${ }^{4}$ Prof., Departamento de Agronomia, Universidade Tecnológica Federal do Paraná, UTFPR, Pato Branco, PR, Brasil. Funded by CNPQ. E-mail: regisluismissio@gmail.com

${ }_{5}$ Pós-Doutoranda do Programa de Pós-Graduação em Agronomia, UTFPR, Pato Branco, PR, Brasil. E-mail: denise.elejalde@ gmail.com

${ }^{6}$ Discente do Curso de Graduação em Zootecnia, UFT, Araguaína, TO, Brasil. E-mail: riccierefederal@hotmail.com

* Author for correspondence
} 
carcaça não foram alteradas pelos níveis de glicerina bruta da deita. A elevação do nível de glicerina bruta das dietas elevou o peso ( $\mathrm{kg}$ e \% do peso de carcaça fria) do dianteiro, mas não alterou os pesos (kg e \% do peso de carcaça fria) do traseiro especial e da ponta de agulha. Dentre os cortes comerciais preparados para comercialização do traseiro especial apenas o peso da picanha (\% peso de carcaça fria) foi alterado com o avanço do nível de glicerina bruta das dietas, diminuindo linearmente. As características da carne não foram alteradas pelo aumento do nível de glicerina bruta das deitas. A inclusão de até $240 \mathrm{~g} \mathrm{~kg}^{-1}$ de glicerina bruta em dietas a base de grão de milheto não altera as principais características de carcaça e carne com importância econômica.

Palavras-chave: Cor. Força ao cisalhamento. Glicerol. Marmoreio. Picanha. Subproduto.

\section{Introduction}

Biodiesel is produced via transesterification, involving methanol or ethanol and carried out in the presence of a basic catalyst. The reaction yields three molecules of methyl esters (biodiesel) and one molecule of crude glycerin. Acid treatment is then used to neutralize the catalyst and remove the fatty acids that are formed occasionally. Approximately $80 \%$ of the resulting mixture is glycerol, water, methanol, and dissolved salts (MOTA et al., 2009). In these times of economic crisis, crude glycerin, which is often produced in quantities that exceed its industrial demand (for drugs, soaps, cosmetics, etc.) and which was considered a potential source of environmental contamination, is being considered as a feed additive that can help reduce the cost of feeding ruminants. In this context, the 194 million animals of the Brazilian bovine herd (ANUALPEC, 2014) display great potential for commercial absorption of this by-product, utilized normally as a substitute for dietary corn (CHANJULA et al., 2014).

Increase in the availability of crude glycerin in the market, as well as its effects on animal performance and quality of the carcass of ruminants have been the target of many studies. However, the results obtained are controversial (LAGE et al., 2010; FRANÇOZO et al., 2013). In general, animal performance is expected to improve since crude glycerin enhances the efficiency of energy utilization by the animal, as reported by Françozo et al. (2013). With respect to the carcass, the inclusion of crude glycerin tends to increase the proportion of fat (VAN CLEEF et al., 2014). This might affect carcass fat cover, rate of liquid loss during chilling, and meat characteristics
(WEBB; O’NEILL, 2008; ZHU et al., 2011). An increase in the carcass fat content might also affect the weight of the carcass commercial cuts (MISSIO et al., 2015). Besides, inclusion of glycerin in ruminant diets increases the meat intramuscular fat by increasing the ruminal production of gluconeogenic precursors (DONKIN, 2008; CHANJULA et al., 2014), thereby altering the physicochemical composition of the meat (CARVALHO et al., 2014). However, similar to its effects on animal performance (HALES et al., 2013), it is likely that the effect of crude glycerin on the carcass and meat characteristics depends, among other factors, on the composition of the diet. In this context, millet grain can be utilized at times when corn prices are on the rise, replacing it totally or partially in the cattle diet. This strategy in diet formulation allows for reduction in feed cost in the feedlot while maintaining animal performance and carcass characteristics similar to those obtained with the corn grain diet (SILVA et al., 2014; ALENCAR et al., 2015).

Therefore, the objective of the present study was to evaluate the physical composition of the carcass and commercial carcass cuts and the characteristics of meat from Nellore young bulls fed in the feedlot with millet grain-based diets containing increased levels of crude glycerin.

\section{Material and Methods}

Twenty-eight 18-month-old Nellore young bulls, with an initial average body weight of $357 \pm 23.56$ $\mathrm{kg}$ were used. The animals were kept in individual concrete floor stalls $\left(12 \mathrm{~m}^{2}\right)$ with troughs for food 
and water. At the beginning of the adaptation phase $(21 \mathrm{~d})$, all animals were dewormed and supplemented with vitamins A, D, and E. Four diets were formulated to meet the requirements for growth and finishing with dry matter intake of 24 $\mathrm{g} \mathrm{kg}^{-1}$ body weight (BW) according to the NRC
(1996). These diets included elephant grass silage as forage and concentrates composed mainly of millet, soybean meal, and crude glycerin (Table 1). The treatments were diets containing increasing levels of crude glycerin $\left(0,60,120\right.$, and $240 \mathrm{~g} \mathrm{~kg}^{-1} \mathrm{DM}$ of diets), maintaining the ratio of $20 \%$ forage (Table 2).

Table 1. Chemical composition of ingredients $\left(\mathrm{g} \mathrm{kg}^{-1}\right.$ of DM)

\begin{tabular}{lccc}
\hline \multirow{2}{*}{ Nutrient } & \multicolumn{3}{c}{ Ingredient } \\
\cline { 2 - 4 } & Elephant grass silage & Ground pearl millet grain & Soybean meal \\
\hline $\mathrm{DM}\left(\mathrm{g} \mathrm{kg}^{-1}\right.$ as fed $)$ & 269.20 & 863.40 & 833.70 \\
Ash & 65.40 & 17.60 & 65.00 \\
Crude protein & 45.40 & 117.70 & 463.10 \\
Ether extract & 16.80 & 42.30 & 14.80 \\
Neutral detergent fiber & 683.10 & 132.00 & 141.50 \\
Total carbohydrates & 872.40 & 822.40 & 457.10 \\
Non-fibrous carbohydrates & 189.30 & 690.00 & 315.60 \\
\hline
\end{tabular}

DM - dry matter.

Table 2. Composition of the experimental diets.

\begin{tabular}{lcccc}
\hline \multirow{2}{*}{ Item $\left(\mathrm{g} \mathrm{kg}^{-1}\right.$ of DM) } & \multicolumn{4}{c}{$\mathrm{g} \mathrm{kg}^{-1}$ of crude glycerin } \\
\cline { 2 - 4 } & 0 & 60 & 120 & 240 \\
\hline & Proximate & & \\
Elephant grass silage & 200.00 & 200.00 & 200.00 & 200.00 \\
Ground millet grain & 777.90 & 650.10 & 523.70 & 364.50 \\
Crude glycerin & -- & 60.00 & 120.00 & 240.00 \\
Soybean meal & 37.00 & 61.20 & 87.00 & 138.00 \\
Limestone & 12.00 & 12.00 & 12.00 & 11.50 \\
Urea & 4.00 & 4.00 & 4.00 & 4.00 \\
Mineral mixture ${ }^{\text {a }}$ & 7.00 & 7.00 & 7.00 & 7.00 \\
Sodium chloride & 3.00 & 3.00 & 3.00 & 3.00 \\
Ammonium sulfate & 0.40 & 0.40 & 0.40 & 0.40 \\
Monensin sodium & 0.30 & 0.30 & 0.30 & 0.30 \\
Virginiamycin & 0.30 & 0.30 & 0.30 & 0.30 \\
& Chemical composition & & \\
Dry matter, g kg ${ }^{-1}$ as fed & 746.00 & 735.00 & 722.00 & 674.00 \\
Mineral matter & 43.00 & 46.00 & 47.00 & 57.00 \\
Crude protein & 110.00 & 115.00 & 114.00 & 113.00 \\
Ether extract & 34.00 & 33.60 & 29.40 & 24.00 \\
Neutral detergent fiber & 229.00 & 237.00 & 228.00 & 203.00 \\
Total carbohydrates & 810.00 & 804.00 & 808.00 & 804.00 \\
Non-fibrous carbohydrates & 580.00 & 566.00 & 579.00 & 601.00 \\
Total digestible nutrients & 720.00 & 660.00 & 650.00 & 730.00 \\
Dry matter digestibility & 680.00 & 650.00 & 690.00 & 740.00 \\
\hline
\end{tabular}

${ }^{a}$ Composition: P - 40 g; Ca - 146 g; Na - 56 g; S - 40 g; Mg - 20 g; Cu - 350 mg; Zn 1300 mg; Mn - 900 mg; Iron - 1050 mg; Co - 10 mg; I - 24 mg; Se - 10 mg; F (max.) 400 mg; excipient q.s. - 1000 mg; DM = dry matter. 
The animals were confined for 84 days (21 days of adaptation and 73 days of data collection). They were fed at 1200 and 1700 ad libitum, and adjusted to allow $10 \%$ orts of offered feed (dry matter basis). Animals fasting for 14-16 h were weighed at the beginning and end of the evaluation period. To obtain the average feed intake, feed and orts were also weighed daily. Samples of ingredients and orts from each animal, and ingredients of feed concentrates from mixture preparations were collected weekly to provide representative samples. The samples were placed in plastic bags, labeled, and stored in a freezer at $-10^{\circ} \mathrm{C}$ until laboratory analysis.

Feces for digestibility trial were collected during the last three days of the experimental period. The collection of stool (300 g) was performed manually, after spontaneous defecation and before the fecal bolus reached the floor of the pen, with animals monitored from $06 \mathrm{~h} 00$ until the collection of the sample from the last animal. For the digestibility trial and analysis of nutrients, samples were predried in a forced ventilation oven at $55{ }^{\circ} \mathrm{C}$ for 72 hours and ground in a $1 \mathrm{~mm}$ sieve. From the three ground samples, a composite sample was made and stored in plastic containers for subsequent laboratory analyses. The fecal dry matter excretion was estimated using indigestible neutral detergent fiber (iNDF) according to the methodology of Cochran et al. (1986). The iNDF contents of the samples of feces, feed (roughage and ingredients of the concentrate) and leftovers were obtained after in situ rumen incubation for 240 hours (CASALI et al., 2008). The fecal output ( $\mathrm{kg}$ of DM day1) was calculated as: iNDF intake/iNDF in feces. The digestibility was calculated by the expression: apparent digestibility of nutrients $=[$ (nutrient intake - nutrients excreted)/ nutrient intake].

Standard procedures of AOAC (1995) were adopted to obtain the following components from the feed, orts, and fecal samples: dry matter, mineral matter, crude protein and ether extract. Neutral detergent fiber was determined according to the methodology of Van Soest et al. (1991). Total carbohydrates, non-fibrous carbohydrates, and total digestible nutrients were estimated according Sniffen et al. (1992), wherein: total carbohydrates $=1000$ - (crude protein + ether extract + mineral matter); non-fibrous carbohydrates $=1000$ - (total carbohydrates + neutral detergent fiber); total digestible nutrients $=$ digestible crude protein + (digestible ether extract $* 2.25)+$ digestible neutral detergent fiber + digestible total carbohydrates.

The animals were slaughtered in a commercial slaughterhouse approved by the Brazilian Federal Inspection Service (SIF), following the normal flow of the slaughter line. Prior to slaughter, the animals were subjected to fasting for 14-16 h. After slaughter, the carcasses were identified, divided in half, weighed, washed, and kept in a cold chamber for $24 \mathrm{~h}$ at a temperature varying between 0 and 2 ${ }^{\circ} \mathrm{C}$. During cooling of the carcasses $(0,8,16$, and 24 h), the $\mathrm{pH}$ was recorded in the muscle Longissimus dorsi between the ribs $9^{\mathrm{a}}$ and $11^{\mathrm{a}}$, using a portable $\mathrm{pH}$ meter with insertion electrode. The temperatures of the carcasses $(0,8,16$ and $24 \mathrm{~h})$ were determined in the same region using a digital thermometer stem provided with a metallic insert. The left half of the carcass was separated into primary cuts, where the forequarter was separated from the pistol cut and short ribs between the $5^{\text {th }}$ and $6^{\text {th }}$ rib bones, including neck, shoulder, arm, and five ribs. Through the rib cut at $22 \mathrm{~cm}$ of the vertebral column, the pistol cut was separated from the short ribs, which included ribs from the sixth bone onward, plus the abdominal muscles. Next, the secondary commercial cuts of pistol cut were set aside, weighed, and measured to determine the weights of the trimmed fat, muscle, and bone.

On the right half-carcass, a cut was made between the $12^{\text {th }}$ and $13^{\text {th }}$ ribs to expose the Longissimus dorsi muscle. After $30 \mathrm{~min}$ of exposure to air, muscle coloration $(1=$ dark; 2 = dark red; $3=$ slightly dark red; $4=$ red; and $5=$ bright red $)$, texture $(1=$ very coarse; $2=$ coarse; $3=$ slightly coarse; $4=$ thin; 5 $=$ very thin), and marbling ( 1 to $3=$ traces; 4 to $6=$ light; 7 to $9=$ small; 10 to $12=$ medium; 13 to 15 
$=$ moderate; 16 to $18=$ abundant) were determined according to the method described by Müller (1987). The longissimus dorsi muscle from the $\mathrm{HH}$ section was identified and frozen at $-18^{\circ} \mathrm{C}$. Three months later, two steaks (slices A and B) of $2.5 \mathrm{~cm}$ thickness were removed from the cranial portion of the Longissimus dorsi muscle. Slice A was identified, weighed, conditioned in aluminum trays, thawed for $12 \mathrm{~h}$ at $4^{\circ} \mathrm{C}$ and weighed again to measure thaw loss. Afterwards, steaks were roasted in an oven until their internal temperature reached $70^{\circ} \mathrm{C}$. After the steaks were weighed with and without a tray for obtaining fluid loss during the cooking process. Cooked steaks were then chilled for $24 \mathrm{~h}$ at $4^{\circ} \mathrm{C}$. For each steak (slice A), shear force of the muscle fibers was measured using six extracted, cylinder-shaped cuts with an area of $1.0 \mathrm{~cm}^{2}$, cut perpendicular to the fiber direction in a Warner-Bratzler Shear machine. To evaluate the chemical characteristics of the meat, the samples of Longíssimus dorsi (Slice B), without the fat layer, were dried in a forced-air oven (100 ${ }^{\circ} \mathrm{C}$ ) and ground in a Wiley mill (1 mm particle). The dry matter, mineral matter, crude protein, and ether extract contents in these samples were determined according to AOAC (1995).

The experimental design was the completely randomized, with four treatments (levels of crude glycerin in the diets) and seven replicates (animals). The Shapiro Wilk and Cochran \& Bartlett's tests were performed to evaluate the normality and homogeneity of variances, respectively. After we were satisfied with the assumptions of normality and homogeneity of variances, the data was subjected to analysis of variance and contrasts. Sum of squares of treatments in the contrasts analysis was decomposed into three contrasts: linear $\left(\begin{array}{llll}0 & -1 & 0 & 1\end{array}\right)$ and quadratic effect (0 - 12 -1) crude glycerin levels and diets with or without inclusion of crude glycerin (3 -1 -1 -1). The general mathematical model is represented by $\mathrm{Y}_{\mathrm{ij}}=\mu+\mathrm{S} i+\mathrm{e}_{\mathrm{ij}}$, where $\mu=$ overall mean; $\mathrm{S} i=$ the effect of the diets; $e_{i j}=$ residual random error. The mathematical model used for the temperature and $\mathrm{pH}$ data is represented by $\mathrm{g}_{\mathrm{ijkl}}=\mu+\mathrm{t}_{\mathrm{i}}+£_{\mathrm{j}}\left(\mathrm{t}_{\mathrm{i}}\right)_{+} \mathrm{a}_{\mathrm{k}}$ $+(\mathrm{ta})_{\mathrm{ik}}+\mathrm{e}_{\mathrm{ijk}}$, where $\mathrm{g}_{\mathrm{ijk}}=$ dependent variable; $\mu=$ general average; $t_{i}=i$ treatment effect; $£_{j}(t)_{i}=$ effect of the $\mathrm{j}$ repetition within the $\mathrm{i}$ treatment; $\mathrm{a}_{\mathrm{k}}=\mathrm{k}$ effect period; $\left(\mathrm{t}_{\mathrm{i}^{*}} \mathrm{a}_{\mathrm{k}}\right)=$ interaction between $\mathrm{i}$ treatment and $\mathrm{k}$ period; $\mathrm{e}_{\mathrm{ijk}}=$ residual experimental error. For probability of type I error, $\alpha=0.05$.

\section{Results and Discussion}

The physical composition and edible portion of the carcass (muscle/bone, muscle + fat/bone, muscle/fat) did not change $(\mathrm{P}>0.05)$ in response to the increased crude glycerin levels in the diets (Table 3 ). These results demonstrate that the increased average daily gain $(1.24,1.26,1.41$, and $1.53 \mathrm{~kg}$ day $^{-1}$ for $0,60,120$, and $240 \mathrm{~g}$ of crude glycerin in the diets, respectively) of animals of the present study is not sufficient to change the proportions of muscle, fat, and bone in the carcass. A similar response was also observed for the carcass weights, which did not differ between the diets tested. The cold carcass weights in animals fed diets containing $0,60,120$, and $240 \mathrm{~g}$ of crude glycerin were 230.7 , $236.9,237.4$, and $243.0 \mathrm{~kg}$, respectively. Moreira et al. (2016) published the productive performance results of experimental animals.

Our results with respect to the physical composition of the carcass were similar to those reported previously by Bartoň et al. (2013) and Leão et al. (2013). These authors did not find any change in the carcass physical composition upon supplying $10 \%$ and $24 \%$ of crude glycerin in the diets for cattle, respectively. In contrast, the present results diverged from those obtained by Van Cleef et al. (2014), who reported increased fat content in the carcass of cattle fed diets containing crude glycerin $(0 \%, 7.5 \%, 15.0 \%, 22.5 \%$, and $30.0 \%$ of dry matter). This increased carcass fat content might be associated with the increase in propionate production (WANG et al., 2009). Glycerol is fermented in the rumen to short-chain fatty acids (mainly propionate), and 50-70\% of this glycerol disappears from the rumen in 
up to $4 \mathrm{~h}$ (DONKIN, 2008). The increase in the synthesis of these volatile fatty acids reduces the amount of carbon and hydrogen available for the production of methane gas, thus improving the availability of energy to the animal (TRABUE et al., 2007; CHANJULA et al., 2014). In addition, because of its liquid form, part of the glycerin is absorbed and metabolized in the liver. Glycerol kinase converts glycerol + ATP to glycerol-3phosphate + ADP at triose phosphate, directing the glycerol to gluconeogenesis (KREHBIEL, 2008). With increase in glucose production, blood insulin concentration and lipogenesis are expected to increase, as suggested by Mach et al. (2009) in a study on cattle receiving different levels of glycerol $(0,4,8$ and $12 \%$ of dry matter).

Table 3. Physical composition of carcasses of young bulls fed crude glycerin levels in the diets.

\begin{tabular}{|c|c|c|c|c|c|c|c|c|}
\hline \multirow{2}{*}{ Item } & \multicolumn{4}{|c|}{$\mathrm{g} \mathrm{kg}^{-1}$ of crude glycerin } & \multirow{2}{*}{$\begin{array}{l}\mathrm{CV} \\
(\%)\end{array}$} & \multicolumn{3}{|c|}{ Contrasts, $\mathrm{p}$ - Value } \\
\hline & 0 & 60 & 120 & 240 & & $\mathrm{~L}$ & Q & 0 vs. CG \\
\hline Muscle, kg & 146.03 & 154.57 & 153.12 & 154.28 & 6.40 & 0.156 & 0.217 & 0.078 \\
\hline Muscle, $\%$ & 63.68 & 65.01 & 64.71 & 62.66 & 2.48 & 0.412 & 0.550 & 0.128 \\
\hline Fat, kg & 46.75 & 46.88 & 46.39 & 53.86 & 15.96 & 0.927 & 0.058 & 0.281 \\
\hline Fat, \% & 20.26 & 19.70 & 19.59 & 21.71 & 11.63 & 0.577 & 0.482 & 0.814 \\
\hline Bone, $\mathrm{kg}$ & 37.47 & 37.89 & 38.41 & 39.86 & 8.27 & 0.906 & 0.599 & 0.652 \\
\hline Bone, $\%$ & 16.40 & 15.93 & 16.22 & 16.15 & 5.81 & 0.859 & 0.119 & 0.371 \\
\hline Muscle + Fat/bone & 5.14 & 5.33 & 5.21 & 5.25 & 7.16 & 0.941 & 0.116 & 0.335 \\
\hline Muscle/bone & 3.89 & 4.08 & 3.99 & 3.89 & 5.55 & 0.896 & 0.069 & 0.139 \\
\hline Muscle/fat & 3.17 & 3.35 & 3.33 & 3.03 & 15.29 & 0.396 & 0.538 & 0.630 \\
\hline
\end{tabular}

$\mathrm{CV}=$ coefficient of variation; $\mathrm{L}=$ linear effect of crude glycerin level $(\mathrm{CG}) ; \mathrm{Q}=$ quadratic effect of crude glycerin level; 0 vs. $\mathrm{CG}$ $=$ diets with $v s$. diets without crude glycerin.

Despite maintenance of the carcass physical composition, altered forequarter weight was observed $(\mathrm{P}<0.05)$ as the levels of crude glycerin in the diets increased. The forequarter weight $(\mathrm{kg}$ and $\%$ of cold carcass) increased linearly, whereas the weights and proportions of the short ribs and pistol cut were not affected by the level of crude glycerin in the diets (Table 4). The elevation in the weight and proportion of the forequarter might be associated with the increase in average daily gain, which promotes the manifestation of sexual dimorphism in young bulls fed with the highest levels of dietary crude glycerin. These results, however, demonstrate that sexual dimorphism is not a decisive factor in variation of the carcass physical composition. This might be explained by the observation that the forequarter showed a constant relationship between the weights of the edible portion (muscle + fat) and the bone tissue with the change in body weight, unlike what occurs with the pistol cut and short ribs as demonstrated by Missio et al. (2015). It is noteworthy that unlike what was observed in this study, Van Cleef et al. (2014) did not find alterations in the commercial prime cuts of the carcass of Nellore young bulls fed with different levels of dietary crude glycerin. This can be explained by the lack of variation in the average daily weight gain. Only few studies have evaluated the effect of dietary levels of crude glycerin on the commercial cuts of bovine carcasses, which limits the discussion of our results. However, when the carcass weight remains unaltered, inclusion of crude glycerin in the diet is expected not to affect the primary and secondary commercial cuts, similar to most carcass characteristics (MACH et al., 2009; LEÃO et al., 2013; EGEA et al., 2014). 
Table 4. Commercials cut of Nellore young bulls fed crude glycerin levels in diets.

\begin{tabular}{|c|c|c|c|c|c|c|c|c|}
\hline \multirow{2}{*}{ Items } & \multicolumn{4}{|c|}{$\mathrm{g} \mathrm{kg}^{-1}$ of crude glycerin } & \multirow{2}{*}{$\begin{array}{l}\mathrm{CV} \\
(\%)\end{array}$} & \multicolumn{3}{|c|}{ Contrasts, $\mathrm{p}$ - value ${ }^{1}$} \\
\hline & 0 & 60 & 120 & 240 & & $\mathrm{~L}$ & $\mathrm{Q}$ & $0 v s . \mathrm{CG}$ \\
\hline Forequarter, $\mathrm{kg}$ & 42.03 & 49.10 & 49.65 & 45.73 & 8.39 & 0.017 & 0.133 & 0.953 \\
\hline Forequarter, \% & 39.77 & 41.23 & 40.79 & 39.26 & 3.14 & 0.045 & 0.591 & 0.795 \\
\hline Short ribs, $\mathrm{kg}$ & 11.37 & 12.30 & 13.30 & 12.60 & 9.18 & 0.419 & 0.143 & 0.825 \\
\hline Short ribs, $\%$ & 10.73 & 10.34 & 10.92 & 10.84 & 5.47 & 0.471 & 0.652 & 0.433 \\
\hline Pistol cut, kg & 52.16 & 57.65 & 58.60 & 58.13 & 4.55 & 0.128 & 0.053 & 0.748 \\
\hline Pistol cut, $\%$ & 49.49 & 48.43 & 48.29 & 49.90 & 3.47 & 0.574 & 0.579 & 0.991 \\
\hline
\end{tabular}

Forequarter, $\mathrm{kg}=42.546+1.1865 \mathrm{CG}-0.0442 \mathrm{CG}^{2}, \mathrm{R}^{2}=0.45$; forequarter, $\%=39.953+0.2155 \mathrm{CG}-0.01029 \mathrm{CG}^{2}, \mathrm{R}^{2}=0.40 ; \mathrm{CV}$ $=$ coefficient of variation; $\mathrm{L}=$ linear effect of crude glycerin level $(\mathrm{CG}) ; \mathrm{Q}=$ quadratic effect of crude glycerin level; 0 vs. $\mathrm{CG}=$ diets with $v s$. diets without crude glycerin.

Furthermore, the weight of the meat cuts, bone tissues, and muscle and fat trimmings from the pistol cut did not change $(\mathrm{P}>0.05)$ in response to the increased dietary levels of crude glycerin (Table 5). When expressed in relation to the cold carcass weight, only the proportion of rump cap was modified $(\mathrm{P}<0.05)$ upon elevation in the levels of crude glycerin in the diets, decreasing linearly. This reduction might be associated with the increase in proportion of forequarter upon increase in the dietary crude glycerin levels. The elevation of the forequarter weight in this context is associated with the maintenance of higher growth of muscles as the chuck with increasing age of the animals (JORGE et al., 1997). Thus, because the proportion of the carcass commercial cuts equals $100 \%$, increase in the proportion of one of them implies a reduction in the proportion of another and vice versa. Notably, the variations in weight and/or proportions of the meat cuts can also be explained by the fluctuations in the animal body growth, which begins from the extremities, moving towards the axial skeleton and loin (LAWRENCE; FOWLER, 2005).

No interaction was detected $(\mathrm{P}>0.05)$ between the dietary crude glycerin levels and the time points of evaluation $(0,8,16$, and $24 \mathrm{~h})$ during the chilling period on the temperature of the carcasses (Table 6). The temperature of the carcass decreased $(\mathrm{P}<0.05)$ as the chilling period increased, reaching less than $5^{\circ} \mathrm{C}$ after $16 \mathrm{~h}$, which is the maximum recommended value to ensure the microbiological quality of the meat (DAVE; GHALY, 2011). The crude glycerin levels of the diet, in turn, did not influence $(\mathrm{P}>0.05)$ the temperatures of the carcasses, which is explained by similar fat cover degree and conformation of the carcasses (MOREIRA et al., 2016). According to Klont et al. (1999), heavier carcasses with higher conformation show lesser decrease in temperature, and consequently lesser $\mathrm{pH}$ decline, which is associated with the larger specific surface of the carcasses. The fat cover, in turn, protects the carcass during chilling (WEBB; O’NEILL, 2008), reducing the temperature decline rates, as was reported by May et al. (1992). Besides microbiological control, temperature of the carcasses is also related to $\mathrm{pH}$. Higher temperatures benefit glycolysis, thus elevating the rate of formation of lactate and promoting $\mathrm{pH}$ decline (ZHU et al., 2011). Thus, the similar carcass temperatures explain the similar values obtained for the $\mathrm{pH}$ upon increase in the dietary levels of crude glycerin. It should be noted, however, that other factors such as age, feeding period, breed group, pre-slaughter stress, and chilling rates are also determinants of meat quality (ŠPEHAR et al., 2008). These variation factors were controlled in this study, which explains the results obtained. 
Table 5. Physical composition of pistol cut of Nellore young bulls fed crude glycerin levels.

\begin{tabular}{|c|c|c|c|c|c|c|c|c|}
\hline \multirow{2}{*}{ Items } & \multicolumn{4}{|c|}{$\mathrm{g} \mathrm{kg}^{-1}$ of crude glycerin } & \multirow{2}{*}{$\begin{array}{l}\text { CV } \\
(\%)\end{array}$} & \multicolumn{3}{|c|}{ Contrasts, $\mathrm{p}$ - Value ${ }^{1}$} \\
\hline & 0 & 60 & 120 & 240 & & $\mathrm{~L}$ & Q & 0 vs. CG \\
\hline Rump cap, kg & 1.23 & 1.22 & 1.19 & 1.14 & 9.65 & 0.123 & 0.957 & 0.316 \\
\hline Rump cap, $\%$ & 2.23 & 2.13 & 2.12 & 1.98 & 8.01 & 0.021 & 0.957 & 0.068 \\
\hline Tail of rump, $\mathrm{kg}$ & 1.28 & 1.35 & 1.35 & 1.32 & 10.71 & 0.754 & 0.420 & 0.439 \\
\hline Tail of rump, $\%$ & 2.28 & 2.35 & 2.41 & 2.28 & 6.65 & 0.986 & 0.109 & 0.428 \\
\hline Rump cap, kg & 4.40 & 3.80 & 4.35 & 3.98 & 33.01 & 0.779 & 0.979 & 0.577 \\
\hline Rump cap, \% & 7.93 & 6.72 & 7.65 & 6.94 & 28.54 & 0.609 & 0.908 & 0.406 \\
\hline Tenderloin, kg & 1.78 & 1.85 & 1.91 & 1.88 & 9.39 & 0.348 & 0.357 & 0.261 \\
\hline Tenderloin, $\%$ & 3.22 & 3.28 & 3.40 & 3.28 & 7.11 & 0.726 & 0.265 & 0.515 \\
\hline Blade meat, $\mathrm{kg}$ & 0.93 & 0.90 & 0.97 & 1.08 & 22.39 & 0.392 & 0.912 & 0.636 \\
\hline Blade meat, \% & 1.68 & 1.62 & 1.70 & 1.88 & 21.46 & 0.683 & 0.664 & 0.980 \\
\hline Striploin, kg & 7.17 & 7.25 & 7.22 & 7.54 & 9.69 & 0.168 & 0.470 & 0.647 \\
\hline Striploin, \% & 12.95 & 12.80 & 12.91 & 13.12 & 6.95 & 0.240 & 0.462 & 0.781 \\
\hline Eye of round, $\mathrm{kg}$ & 2.45 & 2.72 & 2.55 & 2.66 & 12.21 & 0.455 & 0.720 & 0.194 \\
\hline Eye of round, \% & 4.43 & 4.82 & 4.55 & 4.66 & 10.42 & 0.687 & 0.672 & 0.279 \\
\hline Knuckle, kg & 4.78 & 5.13 & 4.95 & 5.32 & 7.35 & 0.067 & 0.856 & 0.072 \\
\hline Knuckle, \% & 8.70 & 9.07 & 8.83 & 9.28 & 5.62 & 0.129 & 0.815 & 0.143 \\
\hline Topside, kg & 8.88 & 9.15 & 8.88 & 9.16 & 8.61 & 0.685 & 0.886 & 0.624 \\
\hline Topside, \% & 16.10 & 16.15 & 15.88 & 15.98 & 4.74 & 0.680 & 0.775 & 0.798 \\
\hline Flat, kg & 5.20 & 5.33 & 5.28 & 5.60 & 10.00 & 0.243 & 0.741 & 0.429 \\
\hline Flat, \% & 9.43 & 9.38 & 9.42 & 9.76 & 5.02 & 0.289 & 0.475 & 0.733 \\
\hline Shank, kg & 3.92 & 4.03 & 3.97 & 4.02 & 8.11 & 0.684 & 0.825 & 0.544 \\
\hline Shank, \% & 7.10 & 7.12 & 7.10 & 6.98 & 4.58 & 0.559 & 0.709 & 0.846 \\
\hline Fat trimmings, $\mathrm{kg}$ & 2.01 & 1.86 & 1.99 & 1.78 & 19.34 & 0.435 & 0.753 & 0.495 \\
\hline Fat trimmings, $\%$ & 3.67 & 3.29 & 3.58 & 3.12 & 21.77 & 0.339 & 0.822 & 0.357 \\
\hline Muscle trimmings, $\mathrm{kg}$ & 1.05 & 1.19 & 1.09 & 1.14 & 20.37 & 0.734 & 0.756 & 0.440 \\
\hline Muscle trimmings, $\%$ & 1.94 & 2.09 & 1.96 & 1.99 & 20.22 & 0.994 & 0.815 & 0.698 \\
\hline Bone, $\mathrm{kg}$ & 10.06 & 10.86 & 10.38 & 10.81 & 8.67 & 0.342 & 0.757 & 0.169 \\
\hline Bone, $\%$ & 18.28 & 19.20 & 18.53 & 18.78 & 5.13 & 0.727 & 0.669 & 0.309 \\
\hline Total weight, kg & 42.04 & 42.69 & 42.57 & 43.69 & 7.96 & 0.415 & 0.908 & 0.546 \\
\hline Total yield, $\%$ & 75.63 & 74.02 & 74.28 & 72.42 & 4.30 & 0.111 & 0.986 & 0.173 \\
\hline
\end{tabular}

Rump cap $=2.223-0.0098 \mathrm{CG}, \mathrm{R}^{2}=0.24 ; \mathrm{CV}=$ coefficient of variation; $\mathrm{L}=$ linear effect of crude glycerin level $(\mathrm{CG}) ; \mathrm{Q}=$ quadratic effect of crude glycerin level; 0 vs. $\mathrm{CG}=$ diets with $v s$. diets without crude glycerin. 
Table 6. Temperature and $\mathrm{pH}$ of carcasses, according hours after slaughter, of Nellore young bulls fed crude glycerin levels in the diets.

\begin{tabular}{|c|c|c|c|c|c|c|}
\hline \multirow{2}{*}{ Hours after slaughter } & \multicolumn{4}{|c|}{$\mathrm{g} \mathrm{kg}^{-1}$ of crude glycerin } & \multirow{2}{*}{ Mean } & \multirow{2}{*}{$\begin{array}{l}\mathrm{CV} \\
(\%)\end{array}$} \\
\hline & 0 & 60 & 120 & 240 & & \\
\hline \multicolumn{7}{|c|}{ Temperature } \\
\hline 0 & 32.85 & 34.30 & 34.36 & 33.52 & $33.76 \mathrm{a}$ & \\
\hline 8 & 6.38 & 5.41 & 6.37 & 5.22 & $5.85 b$ & \\
\hline 16 & 2.23 & 1.49 & 2.61 & 1.80 & $2.03 \mathrm{c}$ & 18.45 \\
\hline 24 & 0.12 & 0.02 & 0.05 & 0.15 & $0.09 \mathrm{~d}$ & \\
\hline Mean & 10.40 & 10.31 & 10.85 & 10.17 & & \\
\hline \multicolumn{7}{|c|}{$\mathrm{pH}$} \\
\hline 0 & 6.58 & 6.60 & 6.58 & 6.53 & $6.57 \mathrm{a}$ & \\
\hline 8 & 6.06 & 6.05 & 6.07 & 6.25 & $6.11 \mathrm{~b}$ & \\
\hline 16 & 5.83 & 5.77 & 5.75 & 5.85 & $5.80 \mathrm{c}$ & 3.55 \\
\hline 24 & 5.65 & 5.85 & 5.50 & 5.78 & $5.70 \mathrm{c}$ & \\
\hline Mean & 6,03 & 6,07 & 5,98 & 6,10 & & \\
\hline
\end{tabular}

Means followed by different letters on the column differ significantly $(\mathrm{P}<0.05) ; \mathrm{CV}=$ coefficient of variation; $\mathrm{L}=$ linear effect of crude glycerin level $(\mathrm{CG}) ; \mathrm{Q}=$ quadratic effect of crude glycerin level; $0 v s . \mathrm{CG}=$ diets with $v s$. diets without crude glycerin.

The $\mathrm{pH}$ of the carcasses varied independently (P $>0.05)$ as a function of the level of crude glycerin and of the evaluation period, decreasing as the carcass-chilling period advanced. The reduction in $\mathrm{pH}$ with progression in the chilling period is part of the normal process of transformation of muscle into meat, due to the depletion of muscle glycogen (IMMONEN; PUOKANNE, 2000; IMMONEN et al., 2000). Despite the $\mathrm{pH}$ decline with advance in rigor mortis, the values obtained after $24 \mathrm{~h}$ of chilling can be considered adequate, since they were lower than the value considered the limit (6.0) for obtaining DFD (dark, firm, dry) meat (ALVES et al., 2005). Besides, it should be noted that the results obtained for the $\mathrm{pH}$ of the carcasses were consistent with those reported by Françozo et al. (2013) and Egea et al. (2014). These authors observed that crude glycerin levels in cattle diets did not change the $\mathrm{pH}$ of the carcasses after $24 \mathrm{~h}$ of chilling.

Elevation in dietary crude glycerin levels did not change $(\mathrm{P}>0.05)$ the physicochemical or technological properties of the meat (Table 7). The lack of variations in the final $\mathrm{pH}$ upon increase in the levels of crude glycerin might have been a decisive factor for these results, since the $\mathrm{pH}$ of the meat is related to most of the meat traits evaluated in this study. A higher $\mathrm{pH}$ than the normal range (5.4-5.8), in this context, increases water retention and compromises protein denaturation, tenderness, succulence, and texture of the meat (higher water content within the fiber, larger diameter of the perimysium). On the other hand, $\mathrm{pH}$ below normal values reduces water retention and benefits protein denaturation, tenderness, succulence, and texture in addition to reducing the redox potential and formation of oxymyoglobin (responsible for the bright red color of meat). The $\mathrm{pH}$ might also interfere with the composition of the meat, regulating the loss of liquids and the denaturation rates of proteins, which work on the moisture and protein content of the meat, respectively (ABRIL, et al., 2001; MUCHENJE et al., 2009). 
Table 7. Meat characteristics of Nellore young bulls fed crude glycerin levels in the diets.

\begin{tabular}{|c|c|c|c|c|c|c|c|c|}
\hline \multirow{2}{*}{ Items } & \multicolumn{4}{|c|}{$\mathrm{g} \mathrm{kg}^{-1}$ of crude glycerin } & \multirow{2}{*}{$\begin{array}{l}\mathrm{CV} \\
(\%)\end{array}$} & \multicolumn{3}{|c|}{ Contrasts, $\mathrm{p}$ - Value ${ }^{1}$} \\
\hline & 0 & 60 & 120 & 240 & & $\mathrm{~L}$ & Q & 0 vs. $\mathrm{CG}$ \\
\hline \multicolumn{9}{|c|}{ Physicochemical characteristics } \\
\hline Color, points & 2.68 & 3.67 & 3.16 & 3.23 & 22.14 & 0.588 & 0.105 & 0.335 \\
\hline Texture, points & 3.11 & 3.36 & 2.83 & 3.08 & 18.26 & 0.587 & 0.980 & 0.971 \\
\hline Marbling, points & 2.66 & 3.62 & 4.37 & 3.66 & 24.51 & 0.958 & 0.131 & 0.140 \\
\hline Shear force, $\mathrm{kg} / \mathrm{cm}^{2}$ & 7.25 & 7.71 & 7.41 & 6.76 & 15.57 & 0.439 & 0.287 & 0.925 \\
\hline Humidity, \% & 72.74 & 72.47 & 72.32 & 72.15 & 2.80 & 0.955 & 0.985 & 0.890 \\
\hline Mineral matter, $\%$ & 4.20 & 3.60 & 4.10 & 4.14 & 9.25 & 0.872 & 0.277 & 0.223 \\
\hline Crude protein, $\%$ & 20.58 & 19.93 & 20.25 & 21.85 & 9.04 & 0.860 & 0.732 & 0.859 \\
\hline Ether extract, \% & 3.05 & 3.58 & 3.41 & 3.06 & 29.79 & 0.704 & 0.426 & 0.905 \\
\hline \multicolumn{9}{|c|}{ Technological characteristics } \\
\hline Thaw loss, $\%$ & 10.59 & 10.59 & 8.28 & 8.06 & 33.98 & 0.716 & 0.135 & 0.126 \\
\hline Cooking loss, $\%$ & 26.33 & 24.73 & 25.81 & 23.49 & 18.21 & 0.149 & 0.289 & 0.103 \\
\hline Total loss, $\%$ & 36.93 & 34.70 & 34.10 & 31.56 & 18.42 & 0.240 & 0.162 & 0.881 \\
\hline
\end{tabular}

$\mathrm{CV}=$ coefficient of variation; $\mathrm{L}=$ linear effect of crude glycerin level $(\mathrm{CG}) ; \mathrm{Q}=$ quadratic effect of crude glycerin level; 0 vs. $\mathrm{CG}$ $=$ diets with $v s$. diets without crude glycerin.

The lack of variation in marbling by the dietary crude glycerin levels is another factor that explains the similar characteristics of meat obtained from the experimental diets (Table 7). Marbling is correlated with variation in the chemical composition (especially the fat content), succulence, loss of liquids during thawing and cooking, tenderness, and texture (MOON et al., 2006). In the present study, marbling was classified as "traces," and the only characteristic evaluated that does not have a direct relationship with $\mathrm{pH}$. The results obtained in the present study agreed with most of those reported in literature (LEÃO et al., 2013; EIRAS et al., 2014; EGEA et al., 2014), where inclusion of up to $24 \%$ of crude glycerin did not result in any alteration of marbling. In general, it is reasonable to expect an increase in meat marbling with the inclusion of crude glycerin due to the increase in propionate production and total carcass fat (WANG et al., 2009; VAN CLEEF et al., 2014). According to Pethick et al. (2004), intramuscular fat prefers carbons originating from glucose and lactate, whereas subcutaneous fat prefers those from acetate and acetyl units.
Among the physicochemical characteristics of the meat, the average shear force of the muscle fibers $\left(7.28 \mathrm{~kg} / \mathrm{cm}^{2}\right)$ is noteworthy, as it characterizes the meat as tough. Miller et al. (2001) found that a shear force of $4.3 \mathrm{~kg} / \mathrm{cm}^{2}$ is the point from which the consumer significantly realizes the lower tenderness of the meat, and the acceptability of the meat is significantly reduced as this value is increased. The values obtained in the present study might be related to the genotypes of the animals as well as the carcass-temperature decline pattern. Wheeler et al. (1990) demonstrated that the zebu displayed higher muscle calpastatin concentrations than taurus cattle. Calpastatin inhibits the action of calpain, which is responsible for the post-mortem proteolysis (HUANG et al., 2014). The effect of temperature, however, is related to the shortening of muscle fibers by the cold, which occurs when the temperature during chilling drops suddenly $\left(<10^{\circ} \mathrm{C}\right)$ before the first $10 \mathrm{~h}$ after bleeding (SAVELL et al., 2005). In the present study, the carcasses reached an average temperature of $5.84{ }^{\circ} \mathrm{C}$ for the first $8 \mathrm{~h}$ of chilling, confirming the hypothesis. Additionally, the results obtained in the present study are in line 
with those presented by Mach et al. (2009) and Lage et al. (2014), who did not find alterations in the shear force of muscle fibers upon inclusion of crude glycerin in cattle diets. An increase in meat tenderness is expected with increased marbling upon inclusion of crude glycerin in the diets, since the shear force of muscle fibers reduces as marbling increases, especially in zebu animals (WHEELER et al., 1994).

However, the results of this study disagree with those found by Carvalho et al. (2014), who observed a decrease in the meat color components (lightness) of cattle fed with $12 \%$ and $18 \%$ crude glycerin versus those fed with $0 \%$ and $6 \%$. This is explained by the higher level of ether extract in diets with higher amounts of crude glycerin. Egea et al. (2014), on the other hand, found a decrease in the color of the meat from cattle fed with increasing levels of crude glycerin in their diets $(0 \%, 2 \%$, and $4 \%)$. The authors attributed this to the occurrence of the Maillard reaction in diets with higher levels of crude glycerin. Our results, however, agree with those published by Françozo et al. (2013), Leão et al. (2013), and Eiras et al. (2014), who did not detect alterations in the meat color upon inclusion of crude glycerin in the cattle diets. Contrastingly, Carvalho et al. (2014) found alterations in the chemical composition of the meat from cattle receiving increasing levels of crude glycerin $(0 \%$, $6 \%, 12 \%$, and $18 \%$ ), in which the water content decreased as the ether extract content increased. Further, the authors did not observe alterations in the ash and crude protein contents of the meat, similar to the present study. Lastly, it is noteworthy that the texture, loss of liquids during thawing and cooking, and total liquid loss by the meat observed in this study are similar to the those presented by FRANÇOZO et al. (2013) and LEÃO et al. (2013). These authors, too, did not observe alterations in these traits upon increase in the levels of glycerin in the cattle diets. The observations made on the loss of liquids by these studies are explained by the similar intramuscular fat content, whereas the lack of variation in texture is partly explained by the similar liquid loss by the meat.

\section{Conclusion}

Inclusion of up to $240 \mathrm{~g} \mathrm{~kg}^{-1}$ crude glycerin in millet grain-based diets for feedlot-finished Nellore young bulls does not change the meat yield of the carcasses or the main characteristics of the meat with economic importance.

\section{References}

ABRIL, M.; CAMPO, M. M.; ÖNENÇ, A. Beef colour evolution as a function of ultimate $\mathrm{Ph}$. Meat Science, New York, v. 58, n. 1, p. 69-78, 2001.

ALENCAR, W. M.; RESTLE, J.; MISSIO, R. L.; NEIVA, J. N. M.; MIOTTO, F. R. C.; FREITAS, I. B. Feeding behavior and productive performance of steers fed millet grain-based diets, containing proportions of babassu mesocarp bran. Revista Brasileira de Zootecnia, Viçosa, MG, v. 44, n. 12, p. 425-433, 2015.

ALVES, D. D.; GOES, R. H. T. B.; MANCIO, A. B. Maciez da carne bovina. Ciência Animal Brasileira, Goiânia, v. 6, n. 3, p. 135-149, 2005.

ANUÁRIO DA PECUÁRIA BRASILEIRA ANUALPEC. 21. ed. São Paulo: Instituto FNP, 2014. $303 \mathrm{p}$.

ASSOCIATION OF OFFICIAL ANALYTICAL CHEMISTRY - AOAC. Official methods of analysis. $16^{\text {th }}$ ed. Arlington: AOAC International, 1995.

BARTOŇ, L.; BUREŠ, D.; HOMOLKA, P.; JANČÍK, F.; MAROUNEK, M.; ŘEHÁK, D. Effects of long-term feeding of crude glycerine on performance, carcass traits, meat quality, and blood and rumen metabolites of finishing bulls. Livestock Science, New York, v. 155, n. 1, p. 53-59, 2013.

CARVALHO, J. R. R.; CHIZZOTTI, M. L.; RAMOS, E. M.; MACHADO NETO, O. R.; LANNA, D. P. D.; LOPES, L. S.; TEIXEIRA, P. D.; LADEIRA, M. M. Qualitative characteristics of meat from young bulls fed different levels of crude glycerin. Meat Science, New York, v. 96, n. 2, p. 977-983, 2014.

CASALI, A. O.; DETMANN, E.; VALADARES FILHO, S. C.; PEREIRA, J. C.; HENRIQUES, L. T.; FREITAS, S. G. E.; PAULINO, M. F. Influência do tempo de incubação e do tamanho de partículas sobre os teores de 
compostos indigestíveis em alimentos e fezes bovinas obtidos por procedimentos in situ. Revista Brasileira de Zootecnia, Viçosa, MG, v. 37, n. 2, p. 335-342, 2008.

CHANJULA, P.; PAKDEECHANUAN, P.; WATTANASIT, S. Effects of dietary crude glycerin supplementation on nutrient digestibility, ruminal fermentation, blood metabolites, and nitrogen balance of goats. Asian Australasian Journal Animal Science, Seoul, v. 27, n. 3, p. 365-374, 2014.

COCHRAN, R. C.; ADAMS, D. C.; WALLACE, J. D.; GALYEAN, M. L. Predicting digestibility diets with internal markers: evaluation of four potential markers. Journal of Animal Science, Champaign, v. 63, n. 5, p. 1476-1483, 1986.

DAVE, D.; GHALY, A. E. Meat spoilage mechanisms and preservation techniques: a critical review. American Journal of Agricultural and Biological Sciences, New York, v. 6, n. 4, p. 486-510, 2011.

DONKIN, S. S. Glicerol from biodiesel production: the new corn for dairy cattle. Revista Brasileira de Zootecnia, Viçosa, MG, v. 37, p. 280-286, 2008. Supplement Special.

EGEA, M.; LINARES, M. B.; GARRIDOA, M. D.; VILLODRE, C.; MADRIDB, J.; ORENGO, J.; MARTÍNEZ, S.; HERNÁNDEZ, F. Crude glycerine inclusion in Limousin bull diets: Animal performance, carcass characteristics and meat quality. Meat Science, New York, v. 98, n. 4, p. 673-678, 2014.

EIRAS, C. E.; MARQUES, J. A.; PRADO, R. M.; VALERO, M. V.; BONAFÉ, E. G.; ZAWADZKI, F.; PEROTTO, D.; PRADO, I. N. Glycerine levels in the diets of crossbred bulls finished in feedlot: carcass characteristics and meat quality. Meat Science, New York, v. 96, n. 2, p. 930-936, 2014.

FRANÇOZO, M. C.; PRADO, I. N.; CECATO, U.; VALERO, M. V.; ZAWADZKI, F.; RIBEIRO, O. L.; PRADO, R. M.; VISENTAINER, J. V. Growth performance, carcass characteristics and meat quality of finishing bulls fed crude glycerin-supplemented diets. Brazilian Archives of Biology and Technology, Curitiba, v. 56, n. 2, p. 327-336, 2013.

HALES, K. E.; BONDURANT, R. G.; LUEBBE, M. K.; COLE, N. A.; MACDONALD, J. C. Effects of crude glycerin in steam-flaked corn-based diets fed to growing feedlot cattle. Journal of Animal Science, Champaign, v. 91, n. 8, p. 3785-3780, 2013.

HUANG, F.; HUANG, M.; ZHANG, H.; GUO, B.; ZHANG, D.; ZHOU, G. Cleavage of the calpain inhibitor, calpastatina, during postmortem ageing of beef skeletal muscle. Food Chemistry, New York, v. 1, n. 148, p. 1-6, 2014.
IMMONEN, K.; PUOKANNE, E. Variation of residual glycogen-glucose concentration at ultimate $\mathrm{pH}$ values below. Meat Science. New York, v. 55, n. 3, p. 279-283, 2000.

IMMONEN, K.; RUUSUNENA, M.; HISSA, K.; PUOLANNE, E. Bovine muscle glycogen concentration in relation to finishing diet, slaughter and ultimate $\mathrm{pH}$. Meat Science, New York, v. 55, n. 1, p. 25-31, 2000.

JORGE, A. M.; FONTES, C. A. A.; FREITAS, J. A.; SOARES, J. E.; RODRIGUES, L. R. R.; RESENDE, F. D. de; QUEIROZ, A. C. Rendimento da carcaça e de cortes básicos de bovinos e bubalinos, abatidos com diferentes estágios de maturidade. Revista Brasileira de Zootecnia, Viçosa, MG, v. 26, n. 5, p. 1048-1054, 1997.

KLONT, R. E.; BARNIER, V. M. H.; SMULDERS, F. J. M.; VAN DIJK, A.; HOVING-BOLINK, A. H.; EIKELENBOOM, G. Post-mortem variation in $\mathrm{pH}$, temperature, and colour profiles of veal carcasses in relation to breed, blood haemoglobin content, and carcass characteristics. Meat Science, New York, v. 53, n. 3, p. 195-202, 1999.

KREHBIEL, C. R. Ruminal and physiological metabolism of glycerin. Journal of Animal Science, Champaign, v. 86, p. 392, 2008. Supplement.

LAGE, J. F.; BERCHIELLI, T. T.; SAN VITO, E.; SILVA, R. A.; RIBEIRO, A. F.; REIS, R. A.; DALLANTONIA, E. E.; SIMONETTI, L. R.; DELEVATTI, L. M.; MACHADO, M. Fatty acid profile, carcass and meat quality traits of young Nellore bulls fed crude glycerin replacing energy sources in the concentrate. Meat Science, New York, v. 96, n. 3, p. 1158-1164, 2014.

LAGE, J. F.; PAULINO, P. V. R.; PEREIRA, L. G. R.; VALADARES FILHO, S. C.; OLIVEIRA, A. S.; DETMANN, E.; PAIVA SOUZA, N. K.; LIMA, J. C. M. Glicerina bruta na dieta de cordeiros terminados em confinamento. Pesquisa Agropecuária Brasileira, Brasília, v. 45, n. 9, p. 1012-1020, 2010.

LAWRENCE, T.; FOWLER, V. Growth of farm animals. London: CAB International, 2005. $330 \mathrm{p}$.

LEÃO, J. P.; NEIVA, J. N. M.; RESTLE, J.; MISSIO, R. L.; PAULINO, P. V. R.; MIOTTO, F. R. C.; SANTANA, A. E. M.; SOUSA, L. F.; ALEXANDRINO, A. Carcass and meat characteristics of different cattle categories fed diets containing crude glycerin. Semina: Ciências Agrárias, Londrina, v. 34, n. 1, p. 431-444, 2013.

MACH, N.; BACH, A.; DEVANT, M. Effects of crude glycerin supplementation on performance and meat quality of Holstein bulls fed high-concentrate diets. Journal of Animal Science, Champaign, v. 87, n. 2, p. 632-638, 2009. 
MAY, S. G.; DOLEZAL, H. G.; GILL, D. R.; RAY, F. K.; BUCHAMAN, D. S. Effects of days fed, carcass grade traits, and subcutaneous fat removal on postmortem muscle characteristics and beef palatability. Journal of Animal Science, Champaign, v. 70, n. 2, p. 444-453, 1992.

MILLER, M. F.; CARR, M. A.; RAMSEY, C. B.; CROCKETT, K. L.; HOOVER, L. C. Consumer thresholds for establishing the value of beef tenderness. Journal of Animal Science, Champaign, v. 79, n. 12, p. 3062-3068, 2001.

MISSIO, R. L.; RESTLE, J.; MOLETTA, J. L.; KUSS, F.; NEIVA, J. N. M.; ELEJALDE, D. A. G.; MOURA, I. C. F.; PRADO, I. N.; MIOTTO, F. C. R. Slaughter weights on animal performance, carcass commercial cuts and meat characteristics of cull cows. Semina: Ciências Agrárias, Londrina, v. 36, n. 6, p. 3827-3842, 2015.

MOON, S. S.; YANG, H. S.; PARK, G. B.; JOO, S. T. The relationship of physiological maturity and marbling judged according to Korean grading system to meat quality traits of Hanwoo beef females. Meat Science, New York, v. 74, n. 3, p. 516-521, 2006.

MOREIRA, W. S.; MIOTTO, F. R. C.; RESTLE, R.; MISSIO, R. L.; NEIVA, J. N. M.; MOREIRA, R. V. Crude glycerol levels in pearl millet-based diets for Nellore young bulls in feedlot. Revista Brasileira de Zootecnia, Viçosa, MG, v. 45, n. 1, p. 32-38, 2016.

MOTA, C. J. A.; SILVA, C. X. A.; GONÇALVES, V. L. C. Gliceroquímica: novos produtos e processos a partir da glicerina de produção de biodiesel. Química Nova, São Paulo, v. 32, n. 3, p. 639-648, 2009.

MUCHENJE, V.; DZANA, K.; CHIMONYO, M.; STRYDOM, P. E.; HUGO, A.; RAATS, J. G. Some biochemical aspects pertaining to beef eating quality and consumer health: a review. Food Chemistry, New York, v. 112, n. 2, p. 279-289, 2009.

MÜLLER, L. Normas para a avaliação de carcaças e concurso de carcaças de novilhos. 2. ed. Santa Maria: Universidade Federal de Santa Maria, 1987. 31 p.

NATIONAL RESEARCH COUNCIL - NRC. Nutrient requirements of beef cattle. $7^{\text {th }}$ ed. rev. Washington, DC.: National Research Council. National Academy of Sciences, 1996. 242 p.

PETHICK, D. W.; HARPER, G. S.; ODDY, V. H. Growth, developpment and nutritional manipulation of marbling in cattle: a review. Australian Journal of Experimental Agriculture, Collingwood, v. 44, n. 7, p. 704-715, 2004.
SAVELL, J. W.; MUELLER, S. L.; BAIRD, B. E. The chilling of carcasses. Meat Science, New York, v. 70, n. 3, p. 449-459, 2005.

SILVA, A. H. G.; RESTLE, J.; MISSIO, R. L.; BILEGO, U. O.; FERNANDES, J. J. R.; REZENDE, P. L. P.; SILVA, R. M.; PEREIRA, M. L. R.; LINO, F. A. Milheto em substituição ao milho na dieta de novilhos confinados. Semina: Ciências Agrárias, Londrina, v. 35, n. 4, p. 2077-2094, 2014.

SNIFFEN, C. J.; O'CONNOR, J. D.; VAN SOEST, P. J.; FOX, D. G.; RUSSEL, J. B. A net carbohydrate and protein system for evaluating cattle diets: II. Carbohydrate and protein availability. Journal of Animal Science, Champaign, v. 70, n. 12, p. 3562-3577, 1992.

ŠPEHAR, M.; VINCEK, D.; ŽGUR, S. Beef quality: factors affecting tenderness and marbling. Stočarstvo, Zagreb, v. 62, n. 6, p. 463-478, 2008.

TRABUE, S.; SCOGGIN, K.; TJANDRAKUSUMA, S.; RASMUSSEN, M. A.; REILLY, P. J. Ruminal fermentation of propylene glycol and glycerol. Journal of Agricultural and Food Chemistry, Washington, v. 55, n. 17, p. 7043-7051, 2007.

VAN CLEEF, E. H. C. B.; EZEQUIEL, J. M. B.; D’AUREA, A. P.; FÁVARO, V. R.; SANCANARI, J. B. I. D. Crude glycerin in diets for feedlot Nellore cattle. Revista Brasileira de Zootecnia, Viçosa, MG, v. 43, n. 2, p. 86-91, 2014.

VAN SOEST, P. J.; ROBERTSON, J. B.; LEWIS, B. A. Methods for dietary fiber, neutral detergent fiber, and nonstarch polysaccharides in relation to animal nutrition. Journal of Animal Science, Champaign, v. 74, n. 10, p. 3583-3597, 1991.

WANG, C.; LIU, Q.; YANG, W. Z.; HUO, W.; JDONG, K. H.; HUANG, Y. X.; YANGC, X. M.; HE, D. C. Effects of glycerol on lactation performance, energy balance and metabolites in early lactation Holstein dairy cows. Animal Feed Science and Technology, New York, v. 151, n. 1-2, p. 12-20, 2009.

WEBB, H. A.; O'NEILL, H.A. The animal fat paradox and meat quality. Meat Science, New York, v. 80, n. 1, p. 28-35, 2008.

WHEELER, T. L.; SAVELL, J. W.; CROOS, H. R.; LUNT, D. K.; SMITH, S. B. Mechanisms associated with the variation in tenderness of meat from Brahman and Hereford cattle. Journal of Animal Science, Champaign, v. 68, n. 12, p. 4206- 4220, 1990. 
WHEELER, T. L.; CUNDIFF, L. V.; KOCH, R. M. Effect of marbling degree on beef palatability in Bos taurus and Bos indicus cattle. Journal of Animal Science, Champaign, v. 72, n. 12, p. 3145-3151, 1994.
ZHU, X.; RUUSUNEN, M.; GUSELLA, M.; ZHOUA, G.; PUOLANNE, E. High post-mortem temperature combined with rapid glycolysis induces phosphorylase denaturation and produces pale and exudative characteristics in broiler Pectoralis major muscles. Meat Science, New York, v. 89, n. 2, p. 181-188, 2011. 